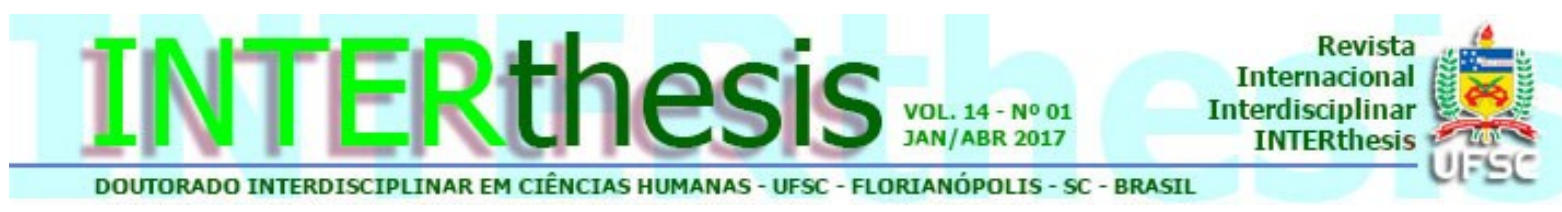

\title{
UM PATRIMÔNIO EM CONFLITO: OS REFLEXOS DOS DISCURSOS DE CIVILIDADE E LAZER NO ANTIGO CEMITÉRIO DA LAGOA EM BARRA VELHA/SC
}

\section{Resumo:}

Angelita Borba de Souza ${ }^{1}$ Euler Renato Westphal²

$\mathrm{O}$ artigo trata dos impactos que o antigo cemitério da lagoa localizado em Barra Velha, Santa Catarina, sofreu no decorrer do século XX. Vila de pescadores, Barra Velha compartilhava o antigo campo santo com comunidades vizinhas e os enterros destacavam-se pelo aspecto pitoresco, pois era necessária a utilização de canoas para transportar tanto o defunto quanto os familiares e amigos. Utilizado desde o final do século XVIII, o antigo cemitério foi substituído no ano de 1929 por outro localizado mais ao centro do vilarejo, e após dezenas de anos servindo a população da região, foi definitivamente abandonado. Símbolo do patrimônio barra-velhense o terreno que abriga os restos mortais dos primeiros habitantes da região sofre as consequências da especulação imobiliária, cujo atual interesse é vender terrenos às margens da lagoa de Barra Velha para turistas de todo o sul do Brasil.

Palavras-chave: Patrimônio. Cemitério. Turismo e Sociedade.

\section{INTRODUÇÃO}

Na segunda metade do século XIX, através da ação de determinados agentes políticos e grupos ligados às ideias liberais, e influência de ideias vivenciadas na Europa, ganhou força irreversível no Brasil o desejo de encerrar a exploração do trabalho escravo, livrar o país de ideias absolutistas e separar o Estado de preceitos católicos. O catolicismo que se destacou como a religião oficial do Estado brasileiro até a proclamação da república passou a ser questionado e suas ações que causaram constrangimentos a seguidores outras crenças sofreram duras críticas a partir da chegada de novos ideais ao Brasil. Era preciso separa o estado civil e o estado religioso. Segundo Rodrigues (2005) o parlamento brasileiro discutiu com frequência a partir de 1860 e com mais fervor nos últimos anos de Brasil Império a

\footnotetext{
1 Mestranda em Patrimônio Cultural e Sociedade pela Universidade da Região de Joinville, Joinville, SC. Gestora da Secretaria de Educação do Estado de Santa Catarina em Joinville, SC, Brasil. E-mail: angelitaborba@hotmail.com

${ }^{2}$ Doutor em Teologia pelo Instituto Ecumênico de Pós-Graduação na Escola Superior de Teologia em São Leopoldo, São Leopoldo, RS. Professor de Ética, Cultura e Sociedade e Pensamento Contemporâneo no Mestrado em Patrimônio Cultural e Sociedade da Universidade da Região de Joinville, Joinville, SC, Brasil. E-mail: eulerwestphal@gmail.com
} 
necessidade de buscar um Brasil moderno e liberal, que se aparelhasse aos novos preceitos vindos da Europa.

Um dos objetivos era mostrar o Brasil como um lugar ordeiro, moderno, laico, higiênico e limpo para atrair os olhares e os investimentos de todas as ordens. $\mathrm{Na}$ busca destes ideais, políticos e outros membros da sociedade iniciaram no decorrer do XIX e fortemente no início do XX uma busca por novas ideais, novos padrões de comportamento nas cidades, nas ruas, em público, no ambiente familiar, em festas, em celebrações fúnebres, enfim, era preciso se adaptar aos novos ideais importados da Europa e abandonar os antigos comportamentos. Outro objetivo perseguido a partir da adoção de novos comportamentos era o de apagar as marcas deixadas pelos séculos de colonização, exploração e escravidão ocorridos no Brasil.

As novas cidades estabeleceram regras que surpreenderam a maioria dos seus usuários e atingiu aqueles que habitavam o coração das cidades e que precisaram abandonar seus espaços para dar lugar a ruas e avenidas largas e bem sinalizadas - sinônimo de grandes centros modernos. Toda a estrutura urbana se transformou, emergindo novas maneiras de se estar na cidade, modos seculares, buscando a sintonia com a cultura europeia, principalmente francesa (CYMBALISTA, 2002, p.65).

Dentre os novos padrões de comportamento, destacamos a transformação pela qual o morto e a morte passaram no Brasil. O corpo do morto e o fenômeno da morte estiveram durante séculos sob a tutela da igreja, que controlava e ensinava os caminhos para a salvação, entretanto, diante da separação entre Igreja e Estado, foram liberados deste domínio. $O$ discurso de secularização ${ }^{3}$ da sociedade atingiu além do morto e da morte, também o cemitério e os rituais fúnebres que deveriam também se encaixar nos discursos de civilidade e organização. O cemitério, território administrado pela igreja católica, sofreu os desdobramentos da secularização, pois, da mesma forma que a cidade dos vivos passou por mudanças, também a cidade dos mortos precisou adaptar-se aos novos ideais. Ele deixa de ser campo santo -

\footnotetext{
${ }^{3}$ A secularização designa, num primeiro momento, um fenômeno jurídico-político: a separação entre as Igrejas e o Estado. Num segundo momento, expressa um progressivo movimento de expulsão da religião do âmbito da esfera pública. O Estado secularizado se apresenta então como o novo fundamento da "lei e ordem", capaz de assegurar aos homens um estado pacificado de convivência. O movimento de circunscrição da religião à esfera do privado se reforça num terceiro momento do processo de secularização, a qual seja: a exigência dos modernos saberes técnico científico experimental e a deslegitimação da teologia como "ciência das ciências", ordenadora da totalidade dos saberes. (BINGEMER, 2003, p.325)
}

R. Inter. Interdisc. INTERthesis, Florianópolis, v.14, n.1, p.19-40 Jan.-Abr. 2017 
benzido e administrado pela igreja - para torna-se necrópole - espaço para o enterro de pessoas de qualquer credo religioso, para a celebração da memória do morto, administrado e organizado por zeladores pagos pela municipalidade.

\section{METODOLOGIA}

Ao optarmos por analisar a história da transferência do antigo cemitério da lagoa em Barra Velha e partirmos para analisar outros locais onde se repete a ação de trocar o seu local de enterramento, entendemos que contribuímos para um melhor entendimento dos fatos que cercam esta mudança. Apesar de parecerem fatos isolados, ao observarmos melhor os acontecimentos descobrimos uma série de especificidades que se repetem em outros locais, como articulações para evitar a troca, resistências veladas ao abandono, interesses religiosos camuflados, interesses econômicos, políticos, dentre outros.

Optamos, portanto em trabalhar a partir dos preceitos da micro-história, pois esta procura demonstrar as especificidades dos objetos e o valor destas especificidades para a compreensão mais ampla da história. Partimos de Barra Velha, analisando o hábito comum até o ano de 1929 quando os enterros ocorriam no antigo Cemitério da Lagoa, para tentar perceber os interesses envolvidos na transferência do mesmo para um terreno mais ao centro da vila de pescadores. Conforme Ginzburg (2001) é baseado em indícios imperceptíveis para a maioria que se pode descobrir pistas e sinais importantes, e é esta a busca, uma vez que a troca de endereço do cemitério sempre foi explicada como desejada por todos, algo que questionamos.

Conforme Salles (2008) a micro-história procurou através da redução da escala, da análise densa das fontes, da busca indutiva através dos indícios, destacar as especificidades de seus objetos e o valor dessas especificidades para a compreensão mais ampla da história. Assim sendo, acreditamos que dando voz aos pescadores em Barra Velha, responsáveis pelo transporte do defunto e do cortejo até o antigo cemitério da lagoa, e posteriormente cruzando com outras informações coletadas podemos perceber as especificidades, romper $\mathrm{o}$ isolamento e abrir $\mathrm{o}$ diálogo. 
Conforme Leite (2011) o interesse pela cultura oral das classes subalternas ao invés de setores elitistas é conhecido como from below, e é neste sentido que se construirá esta pesquisa. Partimos do cotidiano de pescadores no momento do ritual fúnebre, ou seja, o pescador, sujeito não pertencente a elite, que não fez parte da decisão de mudança do endereço do cemitério - é dos conhecimentos deste homem que partimos.

Investimos nas pistas, nos indícios, nos dados marginais para compreender o momento histórico que a vila de pescadores estava inserida no momento da mudança do endereço do cemitério. Estes nos auxiliaram a descortinar outras possibilidades de pensamento a respeito da transferência, a respeito dos interesses em trazer o cemitério para um espaço mais ao centro, tirá-lo das margens da lagoa, traçar outras possibilidades além daquela que já é senso comum entre muitos e que defende a ideia de que a troca foi um pedido da população e que foi celebrada. $O$ momento da transferência e seus desdobramentos são o "meio através do qual pretendemos enxergar uma questão mais ampla, um problema histórico ou cultural significativo" (BARROS, 2007, p.173).

\section{O RITUAL DA MORTE EM BARRA VELHA}

Em Barra Velha, cidade localizada ao norte de Santa Catarina, o lugar do morto chamou atenção pela localização e também pela forma como o mesmo era acessado na hora da despedida final. A localidade se destacava por suas práticas de enterramento opostas aos praticados no resto do Brasil no transcorrer do século XVIII e parte do XIX, quando os mortos eram preferivelmente enterrados no subsolo das igrejas, para que assim estivessem mais próximos dos santos e das orações.

Vila de pescadores que cresceu com base na agricultura e na pesca, a localidade enterrava seus mortos nas proximidades do mar, nas margens de uma grande lagoa que se estende por aproximadamente 6 quilômetros do centro até encontrar o Rio Itapocu. Utilizado provavelmente desde o século XVIII - acredita-se que o antigo cemitério da lagoa seja um dos mais antigos da região norte de Santa Catarina - o cemitério chama atenção pela forma que os enterros ocorriam.

Pela impossibilidade de acessá-lo por terra (não havia ruas para a região no período) havia a indispensável interferência dos pescadores, que com seus barcos auxiliavam os familiares a transportar o corpo do defunto até o cemitério. É possível 
imaginar a cena: $O$ silêncio sendo quebrado ou pelas preces que pediam a salvação da alma do morto ou pelo barulho do remo atravessando as águas da lagoa.

Os barcos carregavam o caixão, os familiares e amigos do defunto por aproximadamente 4 quilômetros até chegar ao local do enterro, lá o caixão era retirado do barco e o trabalho continuava, pois o local do enterramento era decidido e a cova começava a ser aberta para então continuar o ritual fúnebre. Este pitoresco processo chama atenção pela solidariedade entre os membros da sociedade barravelhense, pela distância determinada para a construção de um cemitério e pela paisagem apreciada pelos participantes durante cortejo.

Provavelmente escolhido em função de epidemias que atingiram a região durante o século $X V I I I$, o cemitério foi utilizado por toda a região até o início do século XX. Segundo Pereira (2004) no ano de 1731, foi proibida a entrada de pessoas oriundas de Barra Velha em São Francisco do Sul em função de um surto de câmara de sangue ${ }^{4}$. Mais de cem anos depois, um novo surto de câmara de sangue ocorreu em Barra Velha e foi pedido o apoio do governo da província na luta contra a doença (A REGENERAÇÃO, 1878). Segundo Delumeau (1989) o tempo da peste é o da solidão forçada, pois afastam-se uns dos outros, e o medo é o senhor destes tempos de insegurança. Os homens têm medo até do ar que respiram, medo dos defuntos, dos vivos, de si mesmo. A presença da peste é um dos pontos mais significativos na separação entre os vivos e os mortos, porque apesar da tradição de convivência entre os dois grupos, o afastamento entre ambos é o que pode garantir a sobrevivência.

A presença da peste e a ausência do poder público na área da saúde fez surgir a necessidade de expulsar os corpos dos mortos por doença para o mais longe possível. Esta talvez seja uma das explicações para a escolha deste lugar as margens da lagoa - há uma distância significativa da vila de pescadores - para abrigar o cemitério de Barra Velha. A presença de doenças cujo tratamento pouco se sabia forçou e apressou o afastamento rápido entre vivos e mortos. Outra possível explicação para a escolha do local é exatamente sua localização, estando às margens da lagoa que tinha ligação com o Rio Itapocu, o cemitério era utilizado também pela população ribeirinha das proximidades de Barra Velha.

\footnotetext{
${ }^{4}$ Trata-se de uma câimbra intestinal- diarreia severa.

R. Inter. Interdisc. INTERthesis, Florianópolis, v.14, n.1, p.19-40 Jan.-Abr. 2017
} 
No tocante a prática dos enterramentos no interior da Igreja - hábito presente nas cidades vizinhas como São Francisco do Sul -, esta não esteve presente no cotidiano de Barra Velha, pois a construção da primeira capela da cidade aconteceu muitos anos após o início da utilização do antigo cemitério da lagoa, somente no ano de 1910. Neste ano os pescadores e moradores se reuniram para construir a primeira capela que foi construída com suas portas viradas para a praia, para abençoar o dia a dia do pescador.

A partir da construção da igreja, muitos velórios ocorreram no seu interior, assim como as missas de corpo presente, e quando o cerimonial terminava, os familiares e amigos se dirigiam até as margens da lagoa, posicionavam o caixão no barco (defunteira) e os pescadores remavam em direção ao cemitério.

Este foi o único destino dos defuntos de Barra Velha até o ano de 1929, quando a vila de pescadores ganha um novo campo santo, localizado nas proximidades da capela construída pelos pescadores e moradores. A capela e o campo santo estão localizados no coração da futura cidade e o abandono do antigo cemitério se dá aos poucos, lentamente, com o passar dos anos e a chegada de novas gerações. Com a inauguração do novo cemitério, muitos corpos foram transferidos, porém muitos ainda se encontram nas margens da lagoa.

Segundo Rodrigues (2005) na virada para o século XX, muitas questões ligadas ao local que o cemitério deveria ocupar nas cidades já estava em discussão e em muitos locais estes já estavam realocados. Dentre as discussões estava a obrigatoriedade deste local ocupar um espaço longe das populações: fora das igrejas e longe do centro das cidades.

Conforme Castro (2004) em Florianópolis desde o início do século XX, discussões acerca da presença do cemitério na entrada da cidade eram estampadas em jornais cotidianamente. Foi a construção da ponte Hercílio Luz, que finalizou o debate forçando a retirada do cemitério do Morro do Vieira e transferindo-o para o bairro Três Pontes - atual bairro do Itacorubi.

Em Barra Velha, no ano de 1929, o cemitério é transferido para o centro da vila de pescadores, nas proximidades da igreja, e existe um documento endereçado à Diocese de Joinville pedindo o benzimento do mesmo. Quem determinou a mudança? Quais foram os interesses em trazer o campo santo para a área central 
da vila de pescadores? Não houve desdobramento da política de secularização dos cemitérios em Barra Velha?

Segundo o senso comum presente na cidade, a troca foi impulsionada pelas dificuldades enfrentadas durante o ritual do enterro. Entretanto, segundo o pescador Silvino Floriano da Costa (2015), de 90 anos, ajudar a enterrar os defuntos era muito fácil. Quando ainda tinha 10 anos, já ajudava o pai também pescador a transportar o cortejo e produzir a cova. E ainda no ano de 1938, quase 10 anos após a inauguração do novo cemitério, é possível verificar enterros no antigo cemitério da lagoa (TRIBUNA DA CIDADE, 1997). Muitas famílias continuaram enterrando seus defuntos no antigo local se recusando a adotar o novo cemitério.

Desta maneira, uma parte dos defuntos permaneceu no antigo local e outra teve seus restos mortais transferidos para o novo cemitério. Muitos moradores adotaram o novo local enquanto outros mostraram sua rejeição ao escolher o cemitério localizado na lagoa como destino final de seus corpos, optando assim por permanecer junto a familiares lá depositados.

\section{O APRENDER A MORRER}

Segundo Rodrigues (2005) a partir dos séculos IV e V a Igreja empreendeu um longo trabalho de clericalização da morte, que tinha como objetivo o controle dos rituais fúnebres pelos representantes eclesiásticos em detrimento do controle exercido pelos membros da família e a substituição do culto privado e familiar pelo público e cristão.

Neste momento os corpos de mártires foram levados para o interior das basílicas e colocados aos cuidados dos bispos e outros membros do eclesiástico, o que acabou despertando no restante da população o desejo que ali também estar. Deste modo a Igreja tomou para si o monopólio das sepulturas e sepultamentos, em um processo que pouco a pouco tirou o aspecto familiar e privado da morte e acabou por torná-la domínio público e cristão.

A morte tornou-se um instrumento de dominação e onde houvesse uma Igreja, haveria o temor da morte, da morte despreparada que apontava para a perdição. A morte cristã exigia a preparação do testamento, a escolha do local do enterro, a participação, no momento da morte, de um membro eclesiástico, confissões, enfim, a morte era ensinada em manuais que se tornaram famosos no 
Brasil do século XVIII. A preparação do testamento estava aparelhada a busca pela boa morte e pela salvação. Cabe salientar que estes objetivos em nada se parecem com aqueles procurados pela sociedade atual quando se cogita a ideia de produzir um testamento, hoje, ele é pensado e redigido com o objetivo de transmissão de bens.

Segundo Silva (1996) a Ars Moriendi, era um conjunto de imagens e textos que tinham como objetivo demonstrar como seriam os momentos finais do moribundo preparado para a morte (com testamento, confissão, etc) e não preparado para a morte, além de aprofundar o ideário de que uma boa morte se conquista com uma boa vida. Conforme Vovelle (2010), a ideia de que uma boa morte é a coroação de uma boa vida responde melhor à nova pedagogia da preparação cotidiana para a salvação. Assim, a arte de bem morrer transforma-se, paulatinamente numa escolha de orações e exercícios espirituais que permitem através de uma vida piedosa, aceder a uma boa morte.

Evoluindo do século XV até o XVIII, esta arte de bem morrer ganha forças com a idealização do purgatório, que seria um lugar intermediário para aqueles que ainda possuiam contas a acertar. Se aparelhando aos manuais e estudando os textos e imagens da Ars Moriendi, o cristão esperava ser salvo no julgamento final, que segundo os preceitos cristãos aconteceria no seu leito de morte. Conforme Silva (1996) a ideia do purgatório, é a mais impressionante invenção da teologia cristã medieval, e é nela que se observa o nascimento de uma perspectiva de salvação, que a igreja se apressou em dominar para ensinar os meios de conquistar.

Desta forma a Igreja chama para si a responsabilidade pela salvação das almas e se apropria pouco a pouco do pré morte, da morte em si, do local do enterramento e do pós morte. Segundo Ariés (2012) durante a idade média ou ainda entre os séculos XVI e XVII pouco importava a destinação exata dos ossos, contando que permanecessem perto dos santos, e com o corpo confiado à Igreja. Para Reis (1991) a proximidade física entre cadáver e imagens divinas, representava um modelo de contiguidade espiritual que se desejava obter. A igreja era uma das portas de entrada do paraíso.

Assim, a morte foi arrastada das estradas que davam acesso às cidades para o seu interior, para os arredores das igrejas e basílicas, e também para seu interior. Assumindo outro papel entre as sociedades, a morte e o lugar do morto deixam de 
ser evitados, afastados por serem temidos, para serem controlados, aproximados e observados, entretanto ainda temidos.

\section{A MEDICALIZAÇÃO DA SOCIEDADE}

O impacto das epidemias no Brasil colonial provocou uma série de medidas cujo objetivo era amenizar o sofrimento e a dor da população que em meio a um mar de insegurança e incerteza estava entregue ao pânico e ao desespero. A partir do século XIX, a presença da peste no Brasil impulsionou os processos de secularização da sociedade e assim como em outros países deu força ao discurso médico que enfatizava a presença das doenças ligada aos hábitos de higiene.

Segundo Rodrigues (1997) o cenário de dor provocou entre os vivos, um temor relacionado aos mortos, na medida em que difundiu a concepção de que as sepulturas e seus cadáveres eram focos de contaminação. Desde a primeira metade do século XIX, a corte brasileira passou por transformações que tiveram maior adesão a partir da presença da peste e da alta taxa de mortalidade verificada no Brasil do período.

No decorrer deste século, mais precisamente a partir de 1830 o saber médico ganha espaço sendo consultado e valorizado nos momentos de decisão. O Brasil conta com a Sociedade de Medicina, um órgão consultivo do governo, responsável por auxiliar e recomendar caminhos na luta contra as epidemias. Tendo como alvo: a imundície das ruas, a falta de higiene nos matadouros, açougues, armazéns, hospitais, fábricas, prisões, igrejas e cemitérios os profissionais ligados a higiene e a medicina defendiam a tese de que era preciso esquadrinhar a sociedade de modo a produzir locais mais organizados para evitar a degeneração da saúde e a doença.

Conforme Reis (1991) os médicos sanitaristas eram percebidos como heróis nacionais na luta pela vida em detrimento da morte. Segundo Cymbalista (2002) o raciocínio médico conquistava espaços muito além dos círculos de especialistas e impregnava a sociedade como um todo. Através dos conhecimentos destes estudiosos um conjunto de normas e de mecanismos foram impostos à população na busca pela salubridade.

Um segundo ponto de viragem percebido no decorrer do século XIX na corte brasileira, foi a busca do poder público por um projeto de urbanização e organização dos espaços. Com o objetivo de difundir entre a população os ideais de "civilização" 
novos olhares se voltaram para a fruição dos espaços sociais, para a organização e saneamento destes. Havia a necessidade de uma remodelação das cidades, da derrubada de antigos prédios e cortiços para que ruas, praças e avenidas pudessem surgir, imprimindo ares modernos nos centros. $O$ discurso de modernidade varreu para a periferia o que não se encaixava nos novos preceitos.

Para Rodrigues (1997) percebe-se uma associação entre civilização e salubridade pública: o encontro entre os ideais da corte e dos médicos. O hábito do enterro no interior das igrejas passou a ser reprovado, e em nome da saúde dos que frequentavam o local, os cemitérios deveriam localizar-se o mais distante o possível da população.

Conforme Castro (2004) no final do século XIX no contexto de abolição e da República, novos ideais se configuram e tomam força, e os poderes públicos, intervindo sobre a cidade, irão pensá-la livre de velhas práticas nada higiênicas e indevidas para o desenvolvimento de suas potencialidades. Os ideais de cidade disseminados na Europa atingem o Brasil que tentava se livrar da fama de país escravista e se engajar as novas teorias. Era preciso se adaptar para ser considerado um país sério e confiável e consequentemente lucrar a partir do comércio com outros países. O Brasil precisava de uma reestruturação de antigos ideais, era necessária a ruptura com conformismo existente em relação a monarquia, além da busca por participação política, separação entre Igreja e Estado, a liberdade de culto e a secularização dos cemitérios.

As teorias médico-higienistas tentavam convencer a população a respeito do perigo que representava o antigo hábito de se enterrar no interior das igrejas - o chamado enterro eclesiástico - amplamente defendido como uma forma de se chegar aos céus mais rapidamente. $O$ discurso médico pregava a necessidade de normalizar os costumes no Brasil o que levaria ao fim das epidemias e a conquista do progresso.

Segundo os profissionais da saúde, o comportamento em relação a morte era inadequado no Brasil e deveria ser repensado para evitar que maiores calamidades atingissem a população. Para evitar o caos, diversas medidas foram adotadas, apoiadas, incentivadas e divulgadas pelos médicos e autoridades no Brasil do século XIX.

R. Inter. Interdisc. INTERthesis, Florianópolis, v.14, n.1, p.19-40 Jan.-Abr. 2017 
A lei de 1/10/1828 previu a construção dos cemitérios sob a responsabilidade das municipalidades, longe das igrejas e consequentemente, longe do centro das cidades. Inicialmente, havia a tutela da igreja, que deveria benzer os novos terrenos que abrigariam os cemitérios, porém com a constituição de 1891, tudo muda. Ela em seu artigo $72^{\circ}, \S 5^{\circ}$, dizia que "os cemitérios terão caráter secular e serão administrados pela autoridade municipal, ficando livre a todos os cultos religiosos a prática dos respectivos ritos em relação aos seus crentes, desde que não ofendam a moral pública e as leis" (BRASIL, 1828).

Os médicos utilizando-se dos seus conhecimentos científicos conseguiram expulsar os mortos das igrejas, realocando-os em cemitérios com corredores, covas e mausoléus organizados e asseados por zeladores contratados pela municipalidade. O Estado iniciou um movimento para que a Igreja fosse afastada do controle que historicamente exercia sobre os mortos. Destacamos, neste sentido, a presença de um zelador que através da Portaria 21, de 01 de maio de 1930 foi contratado para atuar no vilarejo de Barra Velha (PARATI, Livro de Decretos e Resoluções. 1926 a 1934. p.58).

Em Barra Velha, encontramos uma contradição, pois como já foi citado, houve o pedido de benzimento do novo cemitério, ao mesmo tempo em que há uma iniciativa da municipalidade de tomar conta do local. Enquanto percebe-se no Brasil uma busca pela eliminação dos poderes religiosos no cemitério e em outros setores da sociedade - uma busca pela secularização -, em Barra Velha, caminharam juntos da municipalidade e da religiosidade.

Enquanto o antigo cemitério da lagoa, não possuía zelador, taxas para o enterramento, muito menos covas assimetricamente pensadas, o novo local, ao pensar a presença de um zelador, espera que esta ausência de organização e controle seja solucionada. Se por um lado, a vila estava de acordo com os ideais de organização e secularização perseguidos no Brasil - o controle exercido pela municipalidade/zelador - por outro retornava aos preceitos ligados a morte nos séculos anteriores.

Outra situação questionável é o local do novo cemitério de Barra Velha, inaugurado em 1929. Ele foi construído na área central do vilarejo, nas proximidades da igreja. Quem escolheu o local? Com quais interesses? 
Ano após ano a busca pelo antigo cemitério foi diminuindo, e na década de 80 uma nova ação ocorre no local. Toneladas de areia, que não seriam mais úteis aos planos da prefeitura da cidade, são lançadas nas margens da lagoa e uma parte deste material cobre o que restava das cruzes e lápides. Quem escolheu novamente este local para o descarte da areia? Com quais interesses?

\section{O LAZER AMEAÇA OS RESQUÍCIOS DO ANTIGO CEMITÉRIO DA LAGOA}

A medicina na busca pela solução dos problemas de saúde produziu condições para a mudança de comportamento em relação ao mar. Embasados em ideias médicas, as elites europeias se deslocavam até as áreas litorâneas em busca do mar, sol e ar puro para tratar sua melancolia. Christoffoli (2000) destaca que por volta de 1940, iniciou-se o nascimento da praia moderna e a massificação do seu uso. A partir desta massificação, iniciasse um movimento das cidades para atender ao turista e surge neste momento o mercado imobiliário que pressiona moradores e proprietários na busca pelo lucro.

Estas empresas do mercado imobiliário têm representantes nos mais diferentes segmentos da sociedade, e possuem um poder de pressionar o poder público até que seus objetivos sejam alcançados.

O lazer surgiu como estratégia de alívio das tensões do dia a dia do mundo do trabalho, além de mostrar-se como melhor forma de utilização do tempo livre semanal. As concepções de lazer se modificam no decorrer do século XIX para atender aos turistas que gozam de suas férias na beira da praia, onde as areias passam a representar o espaço dos jogos e da diversão.

Cidade turística, Barra Velha busca desde a segunda metade do século XX, atrair turistas para suas praias e assim ampliar sua arrecadação. Aproveitando-se dos ideais de lazer ligados ao banho de mar, a cidade se empenhou em melhorar sua estrutura para assim entrar na lista de possíveis destinos de moradores da região norte de Santa Catarina.

As cidades balneárias precisaram se preparar para bem receber os visitantes e assim ganhar adeptos e consequentemente receber um apoio financeiro extra. Cresce o interesse pela região litorânea e pelas areias que anteriormente eram evitadas e não possuíam valor financeiro. Terras que apenas atraiam pescadores e 
suas famílias ganham importância ano após ano, chegando a preços absurdos na atualidade.

O tempo ocioso deveria ser preenchido com atividades de prazer, em contato com a natureza para que a saúde trouxesse vida longa. $\mathrm{O}$ tom bronzeado da pele que séculos antes se relacionava ao trabalho braçal e consequentemente a classes inferiores, a partir da década de 1920 se populariza, e ganha espaço. Até os dias atuais o corpo bronzeado é sinônimo de verão, praia, sol, mar, calor e vida.

No Brasil, o século XIX foi o momento em que as novas condutas relacionadas ao mar tomaram força e exigiram das cidades uma mudança estrutural, sanitária, social, econômica e turística. Em Barra Velha a preparação para atender bem ao turista começou com a preocupação ligada a praia e a lagoa que foram alvo de políticas públicas relacionadas a limpeza e a facilitação no acesso.

Dentre as mudanças que visavam enaltecer o potencial turístico de Barra Velha, destacamos: a beira mar que ganhou pavimentação no decorrer das décadas 70 e 80, a ampliação dos sistemas de saneamento e energia, a autorização de loteamentos pelo poder público, a praia que recebeu toneladas de areia, retiradas do fundo da lagoa, no intuito de aumentar a faixa de areia, e a lagoa teve parte de sua extensão aterrada com o objetivo de dar lugar a uma área de lazer.

Entretanto, a preocupação com o turismo atingiu o terreno do antigo cemitério que foi parcialmente aterrado com a areia tirada do fundo da lagoa. Toneladas de areia que foram dispensadas do aterro realizado no início da lagoa foram despejadas nas margens da mesma e inclusive sobre os vestígios do antigo cemitério. Atualmente é possível encontrar montes de areia em toda a extensão do que seria o local.

O abandono do terreno no ano de 1929 , aliado ao seu aterramento na década de 80 contribuiu para a descaracterização do mesmo. No primeiro momento, a resistência ainda fez com que muitos permanecessem frequentando e utilizando o antigo cemitério da lagoa, algo que o manteve ainda presente na memória dos moradores do local. Porém, a partir do segundo se esgotaram muitas possibilidades de visualizar o local, o com isso, o esquecimento foi acelerado.

As gerações atuais frequentam a Quinta dos Açorianos - bairro onde se localiza o antigo cemitério - sem saber da existência do mesmo e o crescimento do bairro se aproxima cada vez mais do terreno. O bairro que já contava com uma 
localização privilegiada - as margens da lagoa da cidade - recebeu da iniciativa privada um novo atrativo. Foi construída na década de 90 uma ponte pênsil que liga o bairro a praia e chama atenção de investidores que a cada ano procuram Barra Velha com o objetivo de possuir uma casa de praia.

Esta ponte, construída e doada ao município pela empresa que administra a venda de lotes no bairro, foi pensada para chamar a atenção dos visitantes e alavancar as vendas. $\mathrm{O}$ objetivo foi alcançado, pois o crescimento do local desde a década de 90 é visível, e a ponte atualmente é um dos cartões postais barravelhense.

O jeito moderno de aproveitar o tempo ocioso e as práticas de lazer influenciaram nas políticas públicas barra-velhenses, que se apoiaram em estratégias para bem receber o turista. Contudo, as estratégias não se preocuparam em preservar e proteger antigos locais, práticas e rituais, auxiliando na exclusão destes e no reforço ao seu apagamento tanto físico quanto memorial.

\section{UM PATRIMÔNIO EM CONFLITO}

O espaço do cemitério é o local onde se materializa uma gama de sentimentos e sistemas mentais de grupos ou famílias; ele é o material que reflete um universo imaterial. A partir da secularização dos cemitérios, abre-se espaço para as novas concepções de morte e morto e dentre elas a individualização. O túmulo é visitado e a aparência do mesmo é alvo de preocupação uma vez que é a materialização da personalidade daquele escondido sob a lápide.

Segundo Dillmann (2013) o mundo católico ocidental no início do século XX se caracterizou pela intensificação do culto aos mortos no cemitério e estas ações contribuíram para a nova visão em relação ao local de enterramento, a ideia de privatização dos túmulos. Parte-se do campo simbólico, abstrato, mental que se constitui como memória e materializa-se no físico - o cemitério com suas sepulturas, jazigos, cruzes, mausoléus, dentre outros.

Para Nora (1993) a memória é a vida, sempre carregada por grupos vivos e, neste sentido, ela está sempre em permanente evolução, aberta à dialética da lembrança e do esquecimento, inconsciente de suas deformações, desconstruções, reconstruções, vulnerável a todos os usos e manipulações. 
Segundo Candau (2011) a memória é resultado da transmissão de um capital de lembranças e esquecimentos que jamais será pura ou uma "autêntica" transfusão memorial, pois está inserida em estratégias identitárias. Sendo assim, as memórias e seus espaços não são espontâneas e naturais, seus agentes definem o que deve e não ser lembrado ou esquecido, fato que ilustra algumas lacunas existentes relacionadas a arquivos de campos de concentração, memórias de guerras, de ditaduras, histórias de cidades, da escravidão. Apagam-se alguns vestígios e outros recebem uma ênfase maior.

Lugares de memória segundo Candau (2011) provocam o sentimento de pertencimento, têm função de reunificar e de dar coesão aos grupos fragmentados. Os lugares são aportes para que a memória possa se manifestar e se pendurar, favorecendo conexões. E para ser lugar de memória é preciso caracterizar uma experiência vivida, transmitir uma memória, sinais e ter conteúdo demográfico.

$\mathrm{O}$ antigo cemitério da lagoa é por excelência um lugar de memória, pois é capaz de fomentar lembranças e despertar sentimentos de pertencimento. A partir dele se manifestam sentimentos relacionados aos primeiros períodos da colonização da cidade, lembranças a respeito das doenças que atingiam a população, testemunhos relativos aos pitorescos rituais de enterramento presentes em Barra Velha oficialmente até 1929.

Assiste-se a partir do abandono e aterramento do local a uma despreocupação relacionada as memórias que ele carrega, memórias que se aportam nele. É um patrimônio cultural barra-velhense que sofreu desde as primeiras décadas do século $\mathrm{XX}$, e que foi atingido por novos ideais ligados ao turismo e ao lazer. Este patrimônio precisava ser esquecido para que novos espaços aparecessem e trouxessem o lucro tanto para o setor imobiliário quanto para o setor público.

Conforme Velho (2006) a heterogeneidade da sociedade complexa modernocontemporânea, aponta para dificuldades e limitações de uma ação pública responsável pela defesa e pela proteção do patrimônio. Empresários da construção civil em busca de lucros cada vez maiores lançam-se em direção aos patrimônios culturais que deveriam ser protegidos e tombados.

Segundo Candau (2011) o termo patrimonium legitima o familiar que mantém a herança. Neste sentido o patrimônio representa os bens materiais produzidos ao 
longo de uma vida de trabalho e que são repassados aos descendentes que se tornarão os tutores, responsáveis pela manutenção do patrimônio herdado. Entretanto, o termo patrimônio vem ao longo dos últimos séculos ganhando novos conceitos e recebendo lugar de destaque nas sociedades que se utilizaram do termo para designar outros bens de posse coletiva ou não e que deveriam receber atenção especial dada a sua importância na construção das sociedades.

Segundo Nogueira (2014) a partir da década de 1970 uma nova relação entre patrimônio cultural e identidades começou a se configurar. Temos a partir deste momento uma pluralidade de singularidades local, tangíveis e intangíveis.

Fonseca (2009) argumenta que diante do novo quadro da política patrimonial, muito mais complexo e desafiador é a necessidade de formular e se implementar políticas com a finalidade de enriquecer a relação da sociedade com seus bens culturais, sem que se perca de vista os valores que justifiquem sua preservação.

Para Funari \& Pelegrini (2009) o desafio posto ao campo do patrimônio está ligado a capacidade de associar a preservação do patrimônio cultural e da memória social ao desenvolvimento urbano. Como conciliar interesses ligados a grandes empreendimentos cujo interesse é eminentemente financeiro com os interesses da preservação dos sentidos relacionados aos bens patrimoniais que carregados de símbolos, memórias, transcendem o tempo e transmitem.

É preciso encarar o problema do crescimento das cidades e seus desdobramentos em territórios que devem ser protegidos, ou as cidades repetirão a história vivida pelo bairro de Copacabana no Rio de Janeiro. Conforme Velho (2006) o bairro foi demasiadamente explorado e na atualidade convive com problemas difíceis de serem solucionados como o crescimento desordenado, a poluição, o barulho e engarrafamento. Os habitantes da praia foram afastados, os prédios se multiplicaram, a temperatura aumentou e o bairro perde aos poucos os atrativos que o fizeram conhecido em todo o Brasil. É a copacabanização - sinônimo de desleixo e pilhagem urbana (VELHO, 2006, p.244)

Este é o desafio de Barra Velha e dos seus munícipes, que necessitam observar seus pontos de história e de memória e fazê-los presentes, ouvindo-os e divulgando-os, para que se ampliem os conhecimentos a respeito do município concomitantemente as possibilidades de crescimento e/ou desenvolvimento turístico. Os diferentes usos ligados ao patrimônio cultural deveriam ocorrer de maneira 
harmônica e assim conviveriam o desenvolvimento turístico e a preocupação com os bens culturais. Abandonar-se-ia assim a política econômica ligada exclusivamente a especulação imobiliária existente nos balneários atualmente, cujo objetivo na maioria das vezes é apenas explorar.

\section{CONCLUSÃO}

A insuficiência de ações efetivas ligadas ao patrimônio histórico e cultural de Barra Velha e a ausência de políticas sustentáveis no que diz respeito ao crescimento urbano municipal levaram ao longo das décadas a perdas significativas do patrimônio municipal.

Não somente em Barra Velha, mas em todas as cidades litorâneas, os pescadores são empurrados para o canto da praia, pois atrapalhavam a fruição do turista, assim como outros aspectos e costumes que ligam a praia aos seus antigos usos. É o uso perverso do espaço, é a exclusão daqueles que originalmente ocupavam o local, aqueles cuja presença depende a sobrevivência da família. $O$ fenômeno da copacabanização pode ser também aqui identificado, pois se observa uma aproximação perigosa entre o poder público e empresas imobiliárias que se instalam na cidade.

A doação da ponte pênsil ao município de Barra Velha pelo grupo imobiliário responsável pelo loteamento no bairro Quinta dos Açorianos, demonstra a aproximação entre o poder público e o privado. A ponte localiza-se nas proximidades do antigo Cemitério da Lagoa e impulsionou a venda de lotes na região. A empresa se utiliza da ponte como propaganda para convencer os possíveis compradores e realizar lucrativos negócios, a municipalidade em contrapartida utiliza a mesma como ponto turístico sendo responsável inclusive pelo custeio dos valores da sua manutenção.

A ponte Hercílio Luz expulsou os mortos da entrada de Florianópolis e assim como a ponte pênsil de Barra Velha, participou dos planos de desenvolvimento do turismo e dos projetos de modernidade empreendidos pelos administradores públicos. A ponte em Barra Velha auxilia na ocupação dos terrenos ainda livres e dentre eles o terreno do antigo cemitério que atualmente está descaracterizado.

A pressão inevitável do capitalismo provavelmente expulsou os mortos das margens da lagoa, pois o lazer nas águas da lagoa e na praia poderia ser evitado 
nas proximidades do antigo cemitério. Afasta-lo para longe da área turística pode ter sido a solução para ampliar as vendas e atender a interesses das empresas imobiliárias locais. Entre atender as teorias científicas que atestavam o perigo do contato entre mortos e vivos e desenvolver o turismo na região da praia, Barra Velha optou pela lucratividade.

Este interesse está escondido nas entrelinhas das falas dos antigos moradores, quando afirmam que a mudança de endereço do cemitério foi boa, porém muitos ainda continuaram durante décadas utilizando os barcos para acessar o antigo local. A rejeição é um sinal de que não houve unanimidade.

Hoje, organizações não governamentais, a associação de moradores do bairro Quinta dos Açorianos e muitos barra-velhenses lutam por meio do IPHAN pela preservação do local e também de outros pontos importantes do patrimônio municipal. Artigos são escritos, livros estão sendo lançados e encontros entre entidades e municipalidade estão ocorrendo pensando em soluções para o impasse. Crescer respeitando o patrimônio e oferecendo opções culturais, turísticas e sustentáveis que atraiam turistas o ano inteiro.

Se o terreno do antigo cemitério da lagoa e outros tantos exemplos de patrimônio histórico e cultural municipal não ocuparem seus espaços, enquanto estiverem ainda na lista de empecilhos ao desenvolvimento não sendo compreendidos e respeitados Barra Velha perecerá e perderá inúmeras possibilidades de oferecer tanto ao morador e quanto ao turista, opções de lazer e turismo diferenciado, cultural, histórico e sustentável.

Conciliar a fruição dos espaços históricos e sua preservação é o desafio dos próximos anos no que diz respeito ao campo do patrimônio cultural barra-velhense. Partindo deste desafio, se poderá pensar em preservação do patrimônio material e imaterial, sustentabilidade e valorização das memórias locais. 


\title{
HERITAGE IN CONFLICT: THE SPEECHES ABOUT CIVILITY AND LEISURE REFLECTIONS IN THE ANCIENT POND CEMETERY IN BARRA VELHA (SANTA CATARINA)
}

\begin{abstract}
:
This article is about the impact suffered by the ancient pond cemetery located in Barra Velha (Santa Catarina) during the twentieth century. Barra Velha is a fisherman village that shared the ancient pond cemetery with neighboring communities where the burials used to call attention for their picturesque aspect, as it was necessary to deliver the ritual by boat. Open by the eighteenth century's end, the ancient cemetery was substituted in 1929 by a new one located downtown, and after a dozen of years serving the region population it was definitely abandoned. A heritage symbol to Barra Velha and the land that takes care of the first region inhabitants' human remains, the region suffers of real estate speculation. Real estate has interest in selling lands in Barra Velha pond margins to tourists from all over Southern Brazil.
\end{abstract}

Keywords: Heritage. Cemetery. Tourism and Society.

\section{UN PATRIMONIO EN CONFLICTO: LOS REFLEJOS DE DISCURSOS DE CIVILIDAD Y OCIO EN EL ANTIGUO CEMENTERIO DE LA LAGUNA DE BARRA VELHA (SANTA CATARINA)}

\section{Resumen:}

El siguiente artículo trata de los impactos que el antiguo cementerio de la laguna ubicado en Barra Velha - SC ha sufrido durante el siglo XX. Un pueblo de pescadores, Barra Velha dividía el antiguo campo santo con ciudades vecinas y los entierros se destacaban por su aspecto pintoresco, pues era necesaria la utilización de canoas para transportar tanto el difunto cuanto sus familiares y amigos. Utilizado desde final del siglo XVIII, el antiguo cementerio fue substituido en el año de 1929 por otro con ubicación más céntrica, e después de decenas de años sirviendo a la población de la región, fue definitivamente abandonado. Símbolo del patrimonio de Barra Velha, el terreno que abriga los restos mortales de los primeros habitantes de la región, sufre las consecuencias de la especulación inmobiliaria, cuyo actual interés es vender los terrenos a la margen de la laguna de Barra Velha para turistas de todo el sur de Brasil.

Palabras clave: Patrimonio. Cementerio. Turismo y Sociedad. 


\section{REFERÊNCIAS}

ARIĖS, Philippe. História da morte no Ocidente: Da idade Média até nossos dias. Tradução Priscila Viana de Siqueira - Ed. Especial. Rio de Janeiro: Nova Fronteira, 2012.

BARROS, José D'Assunção. Sobre a feitura da micro-história In: Opsis, vol.7 n9 jul-dez 2007. Disponível em:

http://www.revistas.ufg.br/Opsis/article/viewFile/9336/6428 Acesso em 23 de julho de 2016.

BRASIL. Lei do Império, de 1 de outubro de 1828. Dá nova fórma ás Camaras Municipaes, marca suas attribuições, e o processo para a sua eleição, e dos Juizes de Paz. Disponível em: < http://www.planalto.gov.br/ccivil 03/leis/LIM/LIM-1-101828.htm >. Acesso em: 10 abr. 2016.

BINGEMER, M. C. L. . Seja feita a vossa vontade (exemplaridade ética e santidade na modernidade tardia). Atualidade Teológica (PUCRJ), Rio de Janeiro, v. 7, n.15, p. 323-343, 2003.

CANDAU, Joël. Memória e Identidade. São Paulo: Contexto, 2011.

CASTRO, Elisiana Trilha. Aqui jaz um cemitério: a transferência do Cemitério Público de Florianópolis, 1923-1926. 2004. 86 f. Trabalho de Conclusão de Curso (graduação) - Universidade do Estado de Santa Catarina (UDESC).

CHRISTOFFOLI, Angelo Ricardo. Cabeçudas 1910 - 1930: a praia como padrão de conduta social. 2000. Dissertação. (Mestrado em Turismo e Hotelaria). Universidade do Vale do Itajaí (UNIVALI), Itajaí/SC.

CYMBALISTA, Renato. Cidade de vivos: arquitetura e atitudes perante a morte nos cemitérios do estado de São Paulo. São Paulo: Annablume/FAPESP, 2001.

DELUMEAU, Jean. História do medo no ocidente 1300-1800: uma cidade sitiada. São Paulo. Companhia das Letras, 1989.

DILLMANN, Mauro. Morte e práticas fúnebres na secularizada República. Porto Alegre início do século XX. 1. edição. Jundiaí - SP: Paco Editorial, 2016. 
FONSECA, Maria Cecília Londres. O patrimônio em processo. Rio de Janeiro. Editora da UFRJ, 2009.

FUNARI, P. P.; PELEGRINI, S.C.A. Patrimônio Histórico e Cultural. $2^{\mathrm{a} e d . ~ R i o ~ d e ~}$ Janeiro. Editora Jorge Zahar, 2009.

GINZBURG, Carlo. O queijo e os vermes: o cotidiano e as ideias de um moleiro perseguido pela inquisição - 9a edição. São Paulo: Companhia das Letras, 1997.

Mitos, emblemas e sinais: morfologia e história $-3^{a}$ edição. São

Paulo: Companhia das Letras, 2001.

LEITE, Francisco Benedito. Micro-História como ferramenta de pesquisa para acesso à antiguidade cristã. In: Revista Theos, vol. 6 n01, julho de 2011.

NOGUEIRA, Antonio Gilberto Ramos. O campo do patrimônio cultural e a história: itinerários conceituais e práticas de preservação. Antíteses. v. 7, n.14, p. 45-67, jul. - dez. 2014.

NORA, Pierre. Entre Memória e História: A problemática dos lugares. Tradução de Yara Aun Khoury. Projeto História, São Paulo, n. 10, p. 7-28, dez. 1993. [cópia digital].

PEREIRA, Carlos da Costa. História de São Francisco do Sul. 2.ed. Editora da UFSC: Florianópolis, 2004.

REIS, João José. A morte é uma festa: ritos fúnebres e revolta popular no Brasil do século XIX. São Paulo: Companhia das Letras, 1991.

RODRIGUES, Claudia. Lugares dos mortos na cidade dos vivos. Rio de Janeiro: Secretaria Municipal de cultura, Departamento Geral de Documentação e Informação Cultural, Divisão de Educação de Editoração, 1997.

. Nas fronteiras do além: a secularização da morte no Rio de Janeiro (séculos XVIII e XIX). Rio de Janeiro: Arquivo Nacional, 2005.

SILVA, Maria Cerqueira da Silva. 0 "Breve aparelho e modo fácil para ajudar a bem morrer hum cristão" do padre Estevão de Castro (1621). 1996. Dissertação. (Mestrado em História da Cultura Portuguesa). Porto. 
VELHO, Gilberto. Patrimônio, negociação e conflito. Mana, Rio de Janeiro, v. 12, n. 1, p. 237-248, abr. 2006 . Disponível em

http://www.scielo.br/scielo.php?script=sci arttext\&pid=S0104 Acesso em 21 jul. 2016.

VOVELLE, Michel. As almas do purgatório, ou, o trabalho de luto. São Paulo: Unesp, 2010.

\section{Documentos Consultados}

Livro de Decretos e Resoluções de Parati. Determinações do período compreendido entre 1926 e 1934.

\section{Jornal Consultado}

ALVIM, Hélio Ramos. O cortejo fúnebre. Tribuna da cidade. Barra Velha, pág. 10, 02 mai.1997.

\section{Sites Consultados}

Planalto. Disponível em:

http://www.planalto.gov.br/ccivil 03/Constituicao/Constituicao91.htm Acesso em: 15 nov.2015.

Biblioteca Nacional Digital. Disponível em:

http://bndigital.bn.br Acesso em 22 out. 2015.

\section{Entrevista}

COSTA, S. F. Silvino Floriano da Costa: Depoimento [julho2015].

Entrevistadora: Angelita Borba de Souza. Barra Velha, 2015. Arquivo particular a autora. Gravação digital.

Artigo:

Recebido em 11 de Abril de 2016.

Aceito em 09 de Setembro de 2016. 